UDC 811.111

DOI https://doi.org/10.32447/2663-340X-2018-4-75-78

\title{
THE CONCEPT OF EVIL IN A. CHRISTIE'S DETECTIVE STORIES
}

\author{
Malanyuk Maria Stepanivna \\ lecturer of \\ the Department of Foreign Languages and Translation Studies \\ Lviv State University of Life Safety \\ Kleparivska street, 35, Lviv, Ukraine \\ Barnych Ivanna Ivanivna \\ lecturer of the Department of Foreign Languages \\ Lviv University of Trade and Economics \\ Tuhan-Baranovskyi Str., 10, Lviv, Ukraine \\ Svydnytska-Ilkiv Natalia Vasylivna \\ lecturer of the Department of Foreign Languages and Translation Studies \\ Lviv State University of Life Safety \\ Kleparivska street, 35, Lviv, Ukraine
}

\begin{abstract}
The paper is focused on the problem of the inner structure of the detective stories by Agatha Christie. Agatha Christie is one of the most known writers of detective stories in the world. She is also one of the best-selling novelist in modern literature. Her special gift to give people a piece of mystery in their lives rendered her to live forever in their minds. She published 66 detective novels and stories, which were translated into 44 languages. Her fertileness was and still is an inimitable art of writing which catching continually the multitude of the readers. The object of the research is to present the inner structure in A. Christie's detective stories, through the prism of literary and stylistic analysis. Through many years researchers were trying to study A. Christie's way of writing focusing on different aspects of her style. They were looking for the answer how she combined plots making the readers so involved into a story. After plenty of studies they assumed that A. Christie's detective stories were so successful because of her plain language which could be compared to Sir A. C. Doyle, who often used many different variants of the word "answered", though for A. Christie there was the word "said" which she seldom used in writing. She also didn't have a custom of introducing new words, rather she was prone to use everyday middle-class English. A. Christie also didn't challenge the readers with vocabulary to ease them be focused on the plot.
\end{abstract}

Key words: A. Christie, detective stories, vocabulary, concept, discourse.

Introduction. The detective stories among many elements such as a crime, a victim, a murderer presents also evil aspect. Evil might be showed as a feature of as well a villain, as a casualty. Many times a victim occurs to be fairly punished by an offender, because of his previous indecent behavior.

Theoretical framework. Romanticism as expressive principle comes to overturn the perception that humanity had about the world, the object, the relation with nature, God, good and evil: "The metaphysical element and the sovereignty of the imagination were characteristics of a time when rationalism had not just overcome but also condemned them as retrogressive residues" [5, p.188]. So, after romanticism, irrational motivations, dreams, and an unfettered imagination became common tools. Moreover, romanticism brings into the foreground the consciousness of indi-

(C) Malanyuk M. S., Barnych I. I., Svydnytska-Ilkiv N. V. The concept of EVIL in A. Christie's detective stories vidual freedom, a fact which changes the aesthetics and also the ethics of literature. Romanticism renewed the area of aesthetics, using as its main tool imagination. This revolutionized the way that images are created in literature: "Since the Renaissance till the end of classicism, the theory of literature was based on the Poetics of Aristotle" [6, p. 47], with the main criterion being the imitation $(\mu$ í $\mu \eta \sigma v)$, the representation of reality. Now the emphasis fell on the expression and not on its imitation. The writer creates his own reality, expresses his psychic world, is a creator, enjoying the possibilities created by his freedom.

The purpose of the study. The study aims to analyze the inner structure of the concept of evil in detective stories by A. Christie. The specific objectives of the present study are: to describe peculiarities of the inner structure of the concept of evil in the detective story by Agatha Christie and to explain the discoursive peculiarities in the detective story by Agatha Christie. 
Research findings. In Evil under the Sun A. Christie implements a past-oriented understanding of evil that have to be identified and those who are guilty should be expelled from the society. In that story she describes a murder of Arlena Marshall, a beautiful actress who is flirting with many men. In people's opinion she is an evil personified and her death for many is seen as a phanerosis of justice. One of characters in that story Stephen Lane, a deranged clergyman, also considers Arlena as a sinful person and his understanding of evil is that: "Nowadays, no one believes in evil. It is considered, at most, a mere negation of good. Evil, people say, is done by those who know no better - who are undeveloped - who are to be pitied rather than blamed. But, Mr. Poirot, evil is real! It is a fact! I believe in Evil as I believe in Good. It exists! It is powerful! It walks the earth! he stopped. His breath was coming fast. He wiped his forehead with his handkerchief and looked suddenly apologetic. - I'm sorry. I got carried away."

That understanding of evil was characteristic for the Golden Age detective stories. In that notion a villain is a deviant who is driven by undeveloped impulses and his behavior lags behind the attitude of the common member of the society. A. Christie also noticed that in her times the distinction between good and evil, right and wrong was becoming unclear and normalized, so she expressed that in Poirot's words: "to remove all romance - all mystery! Today, everything is standardized! (..) That reminds me very much of the Morgue in Paris."

Nevertheless A. Christie through her fertileness developed the view of a criminal character and evil. From the notion of a villain mentioned above she added also a perception that evil might be done by a character who is very much alike to ordinary person. A. Christie presented that statement in The Murder on the Orient Express where she described twelve different individuals involved in a crime. All of them come from various societies. Among them are an Italian salesman, a middle-aged Swedish nurse, a young British governess, a middle-aged British colonel, a Russian princes and her German maid. Those diversity of the nationality and the status is expressed by a character Monsieur Bouc who comments that to Poirot saying: "all around us there are people of all classes, of all nationalities, of all ages." In Poirot's opinion they might be also "linked together - by death". In that case a murderer might not be one of the passengers, but in fact is one of them. Poirot's phrased that by saying: "The impossible cannot have happened, therefore the impossible must be possible in spite of appearances."

In Sad Cypress A. Christie took a step further to present evil in human's behavior. In that detective story a character Elinor Carlisle, who was engaged to Roddy Welman, was accused of committing a murder of her romantic rival Mary Gerrard. Roddy felt in love with Mary after the engagement with Elinor, so it was believed that a crime must be committed by his previous fiancée. During a trial Elinor was calm, but deep inside she was a welter of emotions, so it was described by a character Peter Lord, who was in love with Elinor, by saying: "the human face is (...) nothing more than a mask". Elinor indeed wasn't showing her feelings, but being in fact innocent she was wondering about Mary's death as a kind of possibility that Roddy one day will come back to her: "If Mary Gerrard were to die, for instance, wouldn't Roddy some day acknowledge: 'It was all for the best?'- Elinor wonders to herself. Wouldn't he come back to her-Elinor?"

Showing that attitude A. Christie turns the reader's attention to the inner human's nature which might lead to the evildoing. By presenting the progress in describing evil from a kind of acceptance of a crime (The Murder on the Orient Express) to drawing a psychological portrait of a character who wish to commit a crime (Sad Cypress) A. Christie underlined that evil is an element of every human being, but must be kept in check.

Although evil is repulsive itself, might be perceived as a literary device to show a transition in a character's nature. In mentioned The Murder on the Orient Express A. Christie described a problem and difficulty in administrating the justice by the main characters. From being friends of a victim's family they became villains who punished an offender. One of them even says that murdered victim "deserved what he got".

A. Christie in her detective stories many times was focusing on the just sentence. One of the most important things for her was punishing evil even if sometimes it involved action ordinary people to take matters into their own hands, such was in The Murder in the Orient Express. In that case a villain escaped from justice, because of as Poirot says: "the enormous wealth he had piled up, and owing to the secret hold he had over various persons" even though "there was no questions of his quilt. As a man who was involved in several children's abductions as well murders he faced the justice at last. Even Poirot who was a supporter of a legal system of justice, when he revealed the clue, wasn't against those twelve delivered-justice characters.

That understanding of a legal justice as often inadequate in coping with evil was another reason for A. Christie to demonstrate her views through detective stories. In Sad Cypress Elinor, a character accused of committing a murder, during a trial likened her testimony to an actress's role upon a stage. Her every word was deliberately articulated and scripted by her defense lawyer. Although being a jumble of thoughts she was able to keep it inside, knowing that showing a piece of emotions might be read by the judge as her guilt. For the judge the most important was only to prove she was guilty or not, without delving into her human nature. /In A. Christie's opinion that attempt reduced the complexity of human experiences just to simple verdict "guilty" or "innocent" and didn't align with a human character, where she was seeing the capacity for evil. It was expressed by Christie in Elinor's words: "How queer-Elinor marvels - when anyone says what's true, they strike it out." A. Christie in that kind of attempt 
perceiveda legal system as a battle between lawyers rather than concentration on uncovering the truth.

As was mentioned above A. Christie viewed a legal justice as unable to deal with evil and wrongdoing what she described in another detective story Curtain. This story is the last case of H. Poirot, where he must solve a murder mystery. Poirot is more than sure that suspected character is in fact a murderer, but unfortunately he was able to escape from a justice. As a confirmation famous detective says: "Where $X$ was present, crimes took place (...) X did not actively take part in these crimes." Hidden sense of these words might be existing disadvantages of a legal justice to tell apart evil from good. The problem is presented by A. Christie in conversation between Poirot and one of characters in that story Dr John Franklin, a famous scientist. In that conversation Dr Franklin states that there are tribes in West Africa who believe in "ordeal bean", a kind of poisonous plant which must be consumed by potential suspect to determine his guilty or innocence. Those tribes are convinced that by eatingordeal bean and surviving a person might convinced about his innocence. Poirot in Curtain regretted not having such useful device saying: "It would certainly make my profession much easier, if I could test guilt and innocence so easily." On that words Dr Franklin responded: "After all, (...) what is evil? What is good? Ideas on them vary from century to century. What would you be testing would probably be a sense of guilt or a sense of innocence. In fact, no value as a test at all. (...) Suppose a man thinks that he has a divine right to kill a dictator or money lender or a pimp or whatever, arouses his moral indignation. He commits what you consider a guilty deed - but what he considers an innocent one! What is your poor ordeal bean to do about it, Monsieur Poirot?"

In that view the ordeal bean is a kind of allegory of a legal justice for A. Christie. Through the story she presentsa legal justice coping with evil without no dichotomy, where there are only two possibilities: innocent or guilty. She also describes a legal system engaged only in physical aspect without no detecting thoughts. Although A. Christie certainly knew that sometimes an accused character was not guilty of committing a crime, but indeed, like Elinor, was contemplating a murder.

For A. Christie evilwas complex deed, because of multifaceted human nature. In the stories she presented that in face of justice an accused character was up for committing a crime based on proofs, but without references to human psyche and feelings. A. Christie as the first detective stories' author applied that element, considering it as one of the main impulse in character's behaviour. A good example could be demeanor of twelve characters described in The Murder on the Orient Express, where they couldn't get over the unpunished crime and decided to be assistants of fairness. Evil inflicted here against the villain is some kind excused, because of his previous repulsive acts.But there is still a place for scruples: should they have the right to do it or not? As a confirmation of that it is worth quoting
Poirot's words about administrating justice: "I do not know, Hastings, if what I have done is justified or not justified. (...) I do not believe that a man should take the law into his own hands. (...) But on the other hand, I am the law! As a young man in the Belgian police force I shot down a desperate criminal who sat on a roof and fired at people below. In a state of emergency martial law is proclaimed. By taking Norton's life, I have saved other lives, innocent lives. But still do not know... It is perhaps right that I should not know."

In quoted passage A. Christie expressed her attitude towards interchangeability with the justice in punishing evil. By invoking the past events Poirot suggested that the law was then constructed to deal with evil and as a source of good. Poirot even decided to sacrifice his authority and to become a murderer to successfully cope with evil. Above quotation is also a fragment of the last letter of $\mathrm{H}$. Poirot to his friend Hastings explaining Poirot's crime motive. Famous detective was confident that a murder he committed to administrate justice was a correct act for one reason, but for another wasn't good. He some kind punished himself for that by not taking his medicines what finally caused his death. In described events A. Christie presented ambivalence in character's behaviour, his hesitation in dealing with a crime, and awareness of possible consequences.

To sum up the detective story subgenre was undoubtedly enriched byA. Christie's style of writing. By using a simple language, an intriguing plot, an unexpected ending she brought to the detective stories the novelty and the new quality. In A. Christie's stories could be also observed her respect towards classical medieval authors such as Shakespeare, Tennyson or Webster. It is worth adding that A. Christie as the first author of the detective stories drew attention to emotional element in analyzing the psychological portrait of a villain. In her stories though coping with evil has always two sides: a sense of well-fullfield duty by taking the law into own hands, and a distribution of justice by a legal court.

Conclusion. This paper was focused on analyzing the inner structure of the detective stories by A. Christie perceiving holistically and the interpretation based on studies of this task. The aim of that research was to provide the comparison of a theoretical and practical aspect. To understand a framework of the detective stories a definition of the inner structure of a literary work in modern Poetics was explained. The inner structure though is perceived as a scheme organized according to external and internal rules. That structure is also necessary to communicate between structural content of a literary work.

When going through A. Christie's detective stories the reader is exposed to commune with evil. Evil is presented here as a feature of both a villain and a casualty. In A. Christie's times an evildoer was expected to be expel from the society. But sometimes a legal justice wasn't able to prove someone's guilt and a villain was vindicated. A. Christie also noticed this fact and she gave her 
voice in that case by presenting such events in the detective stories. Many times the characters in her stories were administrating justice in judge's stead. In her opinion sometimes that was the only way to punish an offender. Nevertheless those cases seldom left the reader with a moral dilemma if people have a right to act per procura.
By exploring A. Christie's detective stories the reader has a chance not only to gain an insight into a human nature but also to learn how to controlnegative emotions which could often lead to a felony. These stories are also a good example how destructive feelings might dominate a human behavior and how one might to fall by the wayside.

1. Christie A., Curtain, New York, 2013.

\title{
ЛІТЕРАТУРА
}

2. Christie A., Evil under the Sun, New York, 2011.

3. Christie A., Sad Cypress, New York, 2011.

4. Christie A., The Murder in the Orient Express,New York, 2017.

5. Emandi Maria E., Beginnings of The Gothic: Horace Walpole, Stefan cel Mare University of Suceava, Romania, 2017.

6. Rozanis Stefanos, Researches for Romanticism, Plethron, Athens, 2001.

1. Christie, A. (2013) Curtain, New York: [in English]

\section{REFERENCES}

2. Christie, A. (2011) Evil under the Sun, New York: [in English].

3. Christie, A. (2011) Sad Cypress, New York: [in English].

4. Christie, A. (2017) The Murder in the Orient Express,New York: [in English].

5. Emandi, Maria E. (2017) Beginnings of The Gothic: Horace Walpole, Stefan cel Mare University of Suceava, Romania: [in English].

6. Rozanis, Stefanos (2001) Researches for Romanticism, Plethron, Athens: [in English].

\section{КОНЦЕПТ ЗЛО У ДЕТЕКТИВНИХ ТВОРАХ А. КРІСТІ}

\author{
Маланюк Марія Степанівна \\ старший викладач кафедри іноземних мов та перекладознавства \\ Львівського державного університету безпеки життєдіяльності \\ вул. Клепарівська, 35, Львів, Україна
}

Барнич Іванна Іванівна

старший викладач кафедри іноземних мов

Львівського торгівельно-економічного університету

вул. Туган-Барановського, 10, Львів, Украӥна

Свидницька-Ільків Наталя Василівна

викладач кафедри іноземних мов та перекладознавства

Львівського державного університету безпеки життєдіяльності вул. Клепарівська, 35, Львів, Україна

У статті розкрито лінгводискурсивні характеристики і типи взаємозв 'язку ключового конщепту англомовного детективного дискурсу. Об'єктом дослідження, виконаного у межах когнітивно-дискурсивної парадигми, став ключовий концепт англомовного детективного дискурсу ЗЛО, реалізованийлексичнимизасобамимови в детективному дискурсі, репрезентованому текстами творів представниці британського напрямку класичного детективу A. Крісті. У роботі уперше концепт ЗЛО розглянутий як ключовий в силу його значущьості та «маркованості» в детективному дискурсі, представленому сукупністю тематично співвіднесених текстів, які будуються за певним шаблоном, тема яких визначається з опорою на тематичні слова та логічні предикати, відбір яких зумовлено ситуативними умовами й стосунками комунікантів. Новим також є опис лексичних засобів, шо вербалізують кониепт детективного дискурсу, та визначення семантичних взаємозв'язків лексем на основі валентнісних відношень. Детективний дискурс демонструє такі конститутивні ознаки інституиійного дискурсу як хронотоп, иілі, иінності, типові учасники тощь. Взаємодія стандартизованих персонажів, контекст $i$ зміст комунікації відбивають статуснорольове спілкування, обумовлене соиіальними інститутами і соиіальними відноменнями та відбувається у межах відносин "агент інституту - клієнт інституту», щцо є характерним для інституційсного дискурсу. Детективний дискурс визначено як «м'яку» форму інституційного дискурсу оскільки при незмінних визначальних компонентах структури (таємниця / злочин - розслідування - 3 розкриття таємниці / злочину) $і$ стандартизованому наборі персонажсів («агенти» $i$ «ліснти» інституту), його структура досить варіативна.

Ключові слова: А. Крісті, детектив, лексичні засоби, концепт, дискурс. 